\title{
Job Sheet Development of Electrical Installation in Improving Student Competencies of Electrical Engineering Education Study Program
}

\author{
Dadang Mulyana ${ }^{1}$, Arif Rahman ${ }^{2}$, Mustamam $^{3}$ \\ \{dadang@unimed.ac.id ${ }^{1}$, arifr81@gmail.com², mustamam1965@gmail.com ${ }^{3}$ \} \\ Universitas Negeri Medan, Medan Indonesia ${ }^{1,2,3}$
}

\begin{abstract}
This research aims to develop worksheets to improve student competence in the electrical installation process. The study was conducted at the Department of Electrical Engineering Education, which involved 18 students. The research methodology uses the Dick \& Carey development model, at the review and trial stage the research involved 2 experts, 3 lecturers supporting the course, and 18 students of the Electrical Engineering Education Study Program. Based on the results of testing the job sheet, it is known: 1) the job sheet design expert test states it is suitable for use; 2) test material is known to need to add grounding material to add insight into students in installing and submitting grounding for electrical installations, 3 ) the results of the use of job sheets by students shows the level of ease and effectiveness in using equipment packages prepared as supplemented job sheets that have been prepared.
\end{abstract}

Keywords: Job sheet, competence, electrical installation practice.

\section{Introduction}

In an effort to improve the quality competence of graduates of the State University of Medan, particularly the Faculty of Engineering has been working gradually and continuously to align the curriculum and supporting facilities and infrastructure with the needs of students. One important part in the implementation of the Electrical Lighting Installation course is practical activities, which are real competencies in the field of work in accordance with the SKKNI that has been set. Therefore, one component that supports the improvement of student competencies in addition to the six assignments as described above the practice that is carried out directly by students. The main factor in implementing the practice is the availability of tools, materials and job sheets as a guideline for the implementation of the practice to be implemented.

Job sheet as a teaching material used in the practice of electrical lighting installation does not meet the guidelines of the SKKNI-based curriculum in the Design and Installation of Building Electrical Installations, which is used as a guide to the certification process of Design and Installation of Building Electric Installations as stipulated in the Decree of the Ministry of Manpower and Transmigration number 170 of 2007 concerning the Determination of Indonesian National Work Competency Standards in the electricity sector, the electricity power sub-sector in the field of electricity utilization. This is an important part of the formulation of basic competencies and competency standards that must be achieved by students.

As a practical teaching material, Job sheet is a practice learning tool where the learning sheets are arranged into a unified whole. Learning sheets include: information sheets, instruction sheets, operation sheets, self-check sheet, and evaluation sheet tools. Measuring achievement of 
competencies in the performance test, these learning sheets are not separated from each other or must be a unified whole to achieve learning objectives [1][2][3]. If this job sheet is developed, it is one of the approaches in organizing learning in the field of electrical engineering, and provides detailed guidance to students to carry out learning activities, determines learning materials appropriately, determines when and how long it will take, so that each student has sufficient opportunity to master the tasks given. Likewise, the implementation of evaluation in the form of tests developed by lecturers emphasizes more understanding of cognitive content, has not been focused on measuring students' attitudes and skills in the form of performance tests. This condition is very potential to produce graduates who are not in accordance with the expected competency standards (SKL).

Referring to the above problems, it is necessary to increase the effectiveness and efficiency of the implementation of electrical installation practice activities carried out through the development of systematization and job sheet structure in accordance with competency requirements. Thus, a practice-oriented worksheet is needed that is effort-oriented to support the improvement of student competency achievement.

The Indonesian National Qualification Framework (KKNI) is an embodiment of the quality and identity of the Indonesian people in relation to the national education and training system owned by Indonesia. The quality of education needs to be adjusted to science and technology and the demands of development. Increasing the ability and skills for prospective workforce students is the responsibility of the education world. Education is an integral part that cannot be separated from the process of preparing qualified, strong, and skilled human resources. Through education, prospective employees are qualified, productive and able to compete. For this reason, students as educational products are required to have eight main competencies, namely: (1) communication skills; (2) critical and creative thinking; (3) inquiry / reasoning skills; (4) interpersonal skills; (5) multicultural / multilingual literacy; (6) problem solving; (7) digital information literacy; and (8) technological skills [4][5][6].

Competence helps companies to describe how a person is performing. This is of course related to one's knowledge, expertise, and work ability. Competence represents an important dimension of work for a person. On that basis, it is very necessary to map work competencies and develop competency profiles based on industry qualifications and classifications, types of work, and job descriptions that must be done in each field of work and expertise.

Mapping of work competency in the field of electricity based on the classification and qualifications of the business world and the world of industry is very important, as an effort to improve the quality of Indonesian workers through the world of education and vocational training. The results of this mapping make a positive contribution to the adjustment and curriculum development in vocational schools and training institutions. In addition, it is also the basis for developing learning materials in the electricity sector in schools and in training institutions. The competency profile in the electricity sector can become a reference for the world of work (business and industry) in developing employee HR, and also as a reference for schools in improving the competence of their graduates.

The need for qualified and competent human resources (HR) by the world of work, encourages researchers to map work potentials in the field of electricity in the form of work competency profiles in the field of electricity based on the classification and qualification of the industry for the development of vocational education and training. The work competency profile in the electricity sector based on the qualifications of the electricity business world consists of competency aspects, namely: (1) occupational health and safety (K3); (2) planning; (3) operation; and (4) maintenance. The four aspects of competency are based on the competence of knowledge, skills and work attitudes that must be possessed by someone who is declared 
competent in the electrical installation field. The work competency profile in the electricity sector is based on the classification of large industries, grouped into six basic competencies, namely: (1) basics of electricity; (2) the basics of electronics; (3) maintenance and repair of industrial electrical equipment; (4) electricity operation; (5) electricity management; and (6) occupational safety and health (K3) [7][8][9].

Teaching and learning interactions certainly require clear communication between lecturers and students. Every form of communication requires a certain medium. The form of print media that can be used in practical learning in a laboratory or in a workshop can be; job sheets, information sheets, job sheets, lab sheets, work sheets, reported sheets given to students.

The learning process is a process of communication between educators and students, or between students. In the communication process it can be done verbally, and can also be nonverbally. In learning of course using different media according to what will be learned, a media can be used for the learning process marked by a series of communication activities. So, learning is a process of communication between educators and students or between students to build themselves based on the knowledge and experience gained through interaction with the environment.

Higher education is a continuation of secondary education that is held to prepare students to become members of the community who have academic and/or professional skills who can apply, develop, and or create science, technology and art. Learning in higher education is slightly different from learning in high school or elementary school. Learning in higher education is more focused on students or often referred to as student centered learning. It is assumed that students are already adults. Therefore, lecturers need to make a plan for each meeting in delivering a course. The Department of Electrical Engineering Education as one of the majors in the Faculty of Engineering, Medan State University has the task of educating students to have skills in teaching Electrical Lighting Installation. These skills are obtained through practical activities in workshops/laboratories that require guiding media such as Job sheets. Output expected by students must be able to carry out practice correctly and correctly. In carrying out practical activities each student must have a reference/guideline, so that the practical activities run smoothly. One of the references/guidelines in the implementation of practice is a worksheet. A job sheet is a systematically compiled guideline or practice manual containing objectives, sequence of work instructions, component drawings, size specifications, inspection results, and conclusions about the practice that has been implemented. Job sheet is a printed educational media (a printed type of teaching aid) that supports instructors in teaching skills, whose contents are a set of directions and pictures of how to create or complete a job. So Job sheet is one form of instruction sheet. One of the most dominant aspects in the learning process of electrical installation practice is the existence of a job sheet, because the job sheet is used to guide or handle students in learning and mastering one of the competencies of practical skills taught by the Lecturer. The use of job sheets will reduce the verbalization of the material presented and be able to increase the active role of students in learning, which ultimately is expected to improve student learning outcomes. Existing worksheets in the Department of Electrical Engineering Education Faculty of Engineering (FT) Medan State University need to be reviewed in terms of the use of job sheets when students carry out practice in the laboratory, to overcome these problems research is needed specifically related to learning in the practice of electrical installation practice which uses teaching materials in the form of job sheets.

The teaching method is a method used by the teacher in establishing relationships with students during the course of teaching [10]. Demonstration of learning tools carried out by the instructor is intended to strengthen the content of the material delivered while also being able to show the process of something happening [11]. After a teacher implements a demonstration 
of learning tools, the next activity is to give students practical opportunities. It is intended that students know the working principle of something that is exhibited, know the process of something happening after the demonstration and know the process of using something that is exhibited [12]. If the availability of practical tools to be used is limited, practical activities can be carried out with a group teaching method. So that problems in practice can also be solved as a group. Implementation instructions in practice are: (1) Preparation and planning, including (a) Establishing the objectives to be achieved, (b) Establishing the steps that must be carried out in the demonstration, and (c) Preparing the necessary tools, (2) Implementation, including (a) Making the demonstration of learning tools can be followed by students, (b) Giving each student the opportunity to try so that students feel confident about the truth of a process, (c) Making an assessment of students. Assessment is an effort made to determine whether educational goals and teaching objectives have been achieved or not. Educational assessment is the process of obtaining information about student achievement or performance. The results of the assessment are used to evaluate the mastery learning of students and the effectiveness of the learning process [13].

Practice tests, also commonly called performance tests, are assessment techniques that require students to demonstrate their skills. Practice tests can be written skills tests, identification tests, simulation tests, and work quotation tests. Writing skills tests are used to measure the skills of students expressed on paper, for example students are asked to make designs or sketch images. The ability to design experiments includes how to design the set of equipment used, including examples of written test skills. Simulation tests are used to measure the ability to simulate demonstrating an action without using actual equipment/objects. Job quotation tests are used to measure proficiency in demonstrating real work such as demonstrating how to cook, how to start a machine, or how to use a microscope.

Lighting electrical installations installed in a residential house are electrical installations for generation, distribution, service and use of electric power using a simple construction with a voltage that is used that is low voltage with a power of up to 900 Watts in the use of electricity for residential homes (housing) which is used for lighting needs (lamps) and household appliances. Some simple electrical installations which are the basis for competency in electrical installation include: (1) Single-Incandescent Light Installation, this installation is planned to be installed in a pipe. For the installation of a single incandescent lamp is very simple. For phase cable goes directly to the switch which is continued to incandescent lamp, while for zero cable goes to lamp. (2) Two Incandescent Installation with a Single Switch, Installation of two lamps with a switch, meaning that both lights are sufficiently serviced by a single switch. So in installation, the delivery of the two lights is obtained through a switch. If the two lights are to be served with two switches, there are two ways the chart can be used, namely: (a) the two switches are installed far apart, (b) the two switches are installed in one place. (3) Installation of Two Warehouse Relations Incandescent Lights. In this case one single switch and one exchange switch are installed. The principle is that the switch (switch) near the door has been replaced by a single-pole connector (1), and at the point of lighting 2 an exchange link (2) is installed which acts as a modifying connector. With a single pole connector, it can eliminate the voltage on the exchange connector and lights that can be put out in the blink of an eye. (4) Installation of Incandescent Hallway or Multi-store Home Lighting. The way this installation works is when someone in the hall turns on the lamp using the swap switch 1 then when going to turn off the lights just press the switch exchange 2 only and vice versa. This also applies to terraced houses. In a terraced house this series is installed near the stairs [14]. 


\section{Research Method}

This study applies a survey method, so that the implementation of data collection is done through observation, document recording, and content analysis related to the implementation of electrical installation practice courses. As for the development of the Electrical Installation practice manual and Job sheet, the Research and Development (R\&D) approach is carried out. In the initial stage of the study materials have been developed in accordance with KKNI teaching materials in the KDBK Network and electrical installations related to Electrical Lighting Installation subjects. In the current research, there will be a development of guidelines for the implementation of practice and job sheets of electrical installation practice. The results of the research are expected to be able to find the materials for the practice of electrical installation courses in the form of a Job sheet for student practical activities to support the competence of electrical installations. Systematic research that will be carried out in this study are as follows (1) Analysis of the basic competencies of electrical lighting installations in accordance with the SKKNI and KDBK Electrical installation networks, (2) Preparation of the material framework for electrical installation practices according to the competencies required for the electrical installation scheme, (3) Development of practice sheet work on Electrical Lighting Installation courses for Electrical Engineering education study program students.

The population in this study is supporting documents for the preparation of learning materials and Job Sheets for the Electrical Lighting Installation course, and students of the Electrical Engineering Education study program in the odd semester of the academic year 2018/2019 who took the Electrical Lighting Installation Practice course. The sampling technique uses purposive random sampling. In this study, sampling aims to pay attention to the subject of students who are subjected to the Learning of Electrical Lighting Installation Practices, as well as to pay attention to the competence of Electrical Lighting Installation courses in the Electrical Engineering Education Study Program. The number of sample students is planned as many as 18 people. In developing job sheets, design, material and feasibility tests are used by students majoring in electrical engineering education.

\section{Result and Discussion}

Electrical lighting installation is a compulsory subject in the Department of Electrical Engineering Education. This is because electric lighting installation is very useful in everyday life. Therefore, it is necessary to improve the quality of learning. In this study will develop study guides and practical job sheets complete with packages for the installation of installations that will be carried out during the practice of electrical lighting installation by students both individually and in groups. The use of job sheets and installation practice packages is expected to increase student understanding and increase the competency of installing electrical installations for students.

Basically, practical learning is a direct work process carried out by students with instructor instructions and job sheet guides. The practice process does not always run smoothly, sometimes even the implementation process can cause confusion, misunderstanding, or even wrong concepts. Errors in practical activities can occur because of instructors, students, and learning media used. To avoid or reduce the possibility of miscommunication, media is needed as an intermediary or information distribution process from instructors to students or vice versa. With 
the media job sheet the process of implementing the practice is expected to run faster and in accordance with the objectives. Therefore, it is necessary to have a media that can improve student understanding so that the results of practice and improvement in competence of installation practices can be increased and successful. The media was developed in the form of a practical guide and Job sheet for electrical information installation. This job sheet is used for the competence of installing electrical lighting installations. Through the use of this job sheet, it is assumed to be able to increase student understanding so that the results of student practice can be improved and in accordance with the expected competencies.

\section{Conclusions}

Based on data analysis and research discussion, several conclusions can be drawn, namely : (1) The results of the analysis of design experts, materials, and language show that the integration of theory and the developed job sheets are appropriate for use in the implementation of learning and practice of electrical installations, (2) In general job sheets of electrical installation practice developed to improve student competencies in carrying out electrical installation, (3) Electrical installation theory learning guide becomes a supplement in the implementation of learning electrical installation courses, (4) The results of the implementation of the installation practice by using an electrical installation job sheet can assist students in carrying out the practice and improve competence in the installation of electrical installations, (5) The theory guide and the electrical installation job sheet are developed in accordance with the rules of the learning guide and are able to improve student competency in carrying out electrical installation, (6) The implementation of learning and practice of electrical installations can be carried out effectively and provide convenience to students in completing practice.

\section{Acknowledgements}

Our thanks go to Univeristas Negeri Medan Chancellor, Dean of FT, and Head of Research Institute for their financial assistance and guidance so that this research can be carried out.

\section{References}

[1] Blank, W., E. Handbook For Developing Competency Based Training Program. Englewood Cliff. New Jersey: Prentice Hall, (1982).

[2] Sudjana, Nana. Dasar-Dasar Proses Belajar mengajar. Bandung: Sinar Baru, Aigensindo, (2008).

[3] Handoko, Priyo. Pemasangan Instalasi Listrik Dasar. Yogyakarta: Kanisus, (2000);

[4] Widarto, Pardjono, dan Widodo, Noto. 2012. "Pengembangan Model Pembelajaran Soft Skills dan Hard Skills untuk Siswa SMK”, dalam Cakrawala Pendidikan, XXXI (3), hlm. 409-423, (2012).

[5] Depdiknas. Peraturan Pemerintah RI Nomor 19 Tahun 2005, tentang Standar Nasional Pendidikan, (2005).

[6] Depdiknas. Modul Instalasi Listrik Dasar. Jakarta. (2003).

[7] Depdiknas. Panduan Penilaian Kelompok Mata Pelajaran Ilmu Pengetahuan dan Teknologi. Jakarta, (2007). 
[8] Colley, K. Project-Based Sciense Instruction. TheScience Teacher, 74(8):23-28. (2008)

[9] Har Suhardi, Bambang T, Teknik Instalasi Listrik Penerangan Jilid I, Direktorat Pembinaan Sekolah Menengah Kejuruan, Depdiknas, (2008).

[10] Sudjana, Nana dan, Ibrahim. Penelitian dan Penilaian Pendidikan. Bandung: Sinar Baru Algensindo, (2007).

[11] Pehkonen, Erkki. (1997). The State-of-Art in Mathematical Creativity., Vol. 29, No. 3, 230-245, (1997).

[12] Railsback, J. Project-Basic-Learning: Creating Excitemen for Learning. Northwest Regional Educational Laboratory, (2002).

[13] Made Wena. 2012. Strategi Pembelajaran Inovatif Kontemporer. Jakarta : Bumi Aksara, (2012).

[14] Yahya, M. Efektivitas Penggunaan Jobsheet pada Pembelajaran Praktik Jurusan Pendidikan Teknik Otomotif, FT. UNM, Jurnal FT-UNM, (2014). 